
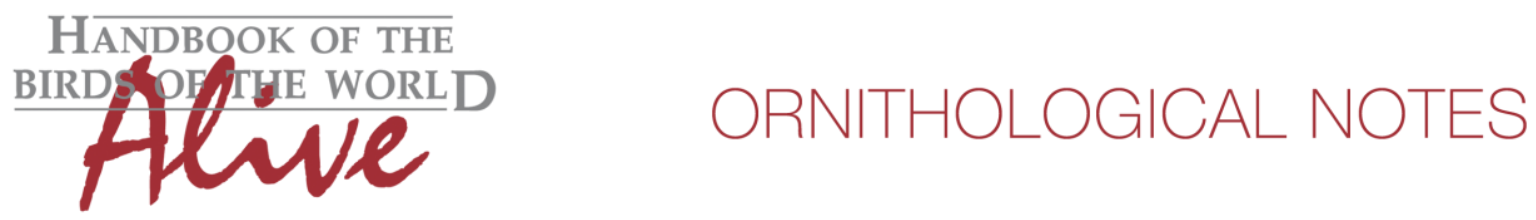

\title{
Notes on the vocalizations of Brown-chested Jungle-flycatcher (Rhinomyias brunneatus)
}

Peter Boesman

In the following we briefly analyze and compare voice of the two races of Brown-chested Jungle-flycatcher (Rhinomyias brunneatus). We also try to quantify the extent of any vocal differences using the criteria proposed by Tobias et al. (2010), as a support for taxonomic review. We have made use of sound recordings available on-line from Xeno Canto (XC).

Nominate seems to have a short song and a more elaborated alternative song.

Short song starts with 1-3 short very high-pitched notes (c. 7-8kHz, hardly audible) followed by remarkably low-pitched whistles (c. 2-3 kHz)(typically 2 followed by a series of 2-4 notes which are slightly higher-pitched and may accelerate towards the end). Duration of the lowpitched phrase c. $1-1.2 \mathrm{~s}$.

Some examples:
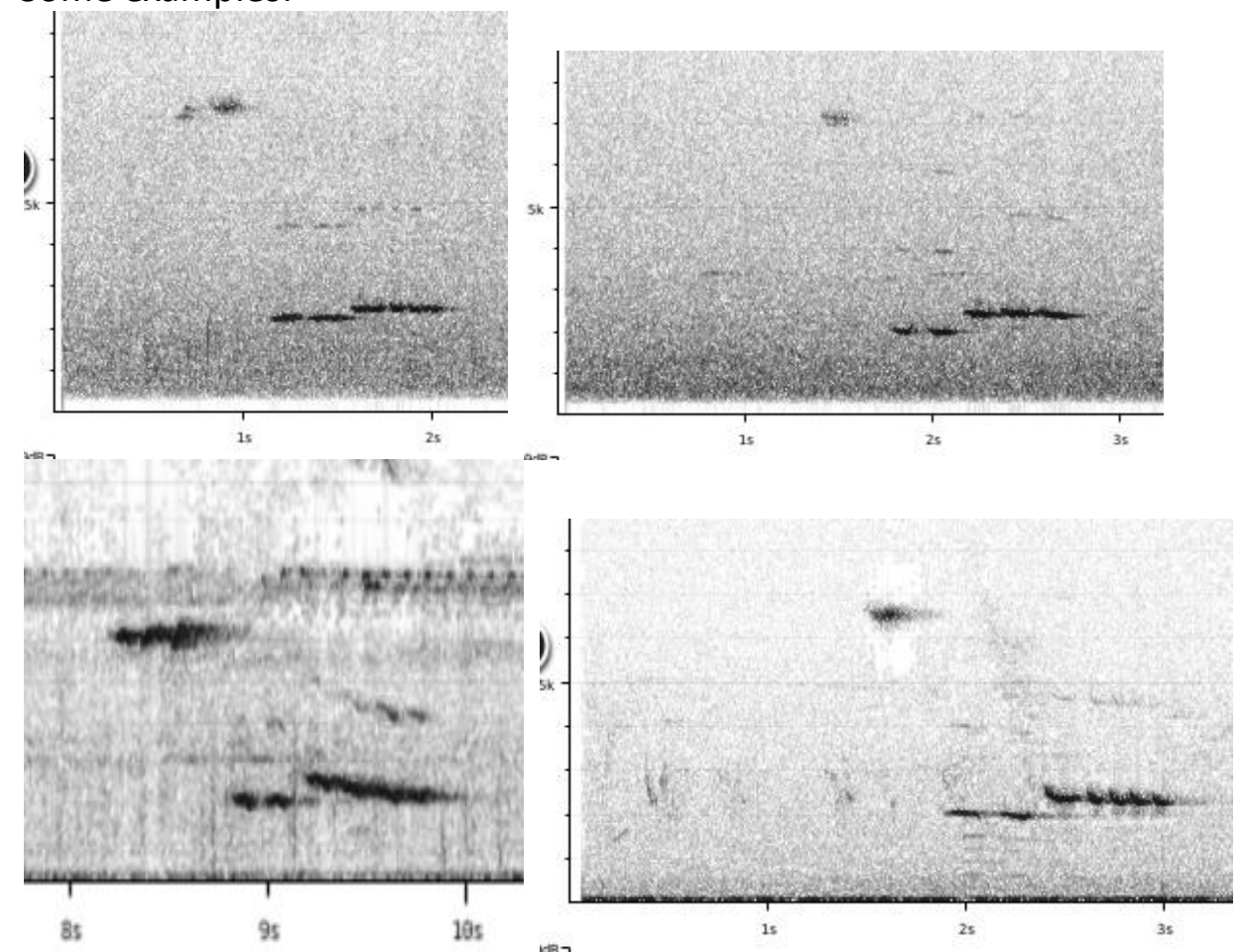

Alternative song, only occasionally heard, is a continuous series of trills and repeated notes:

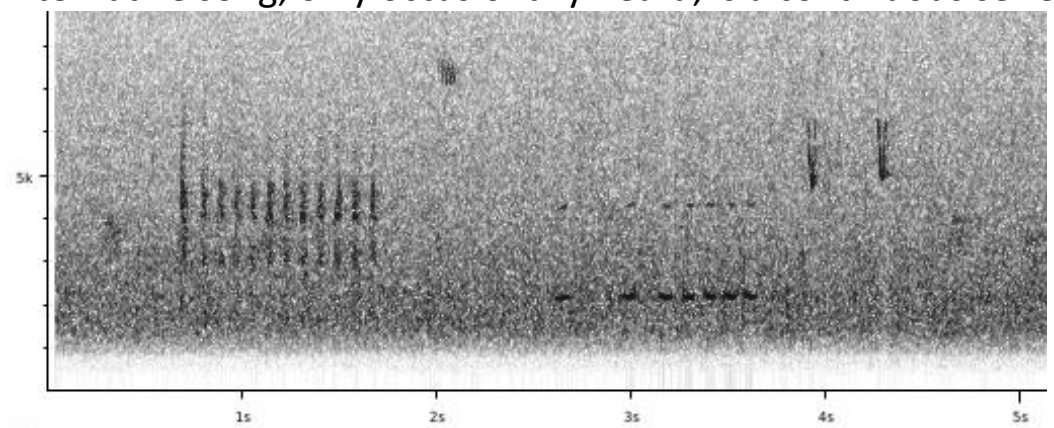



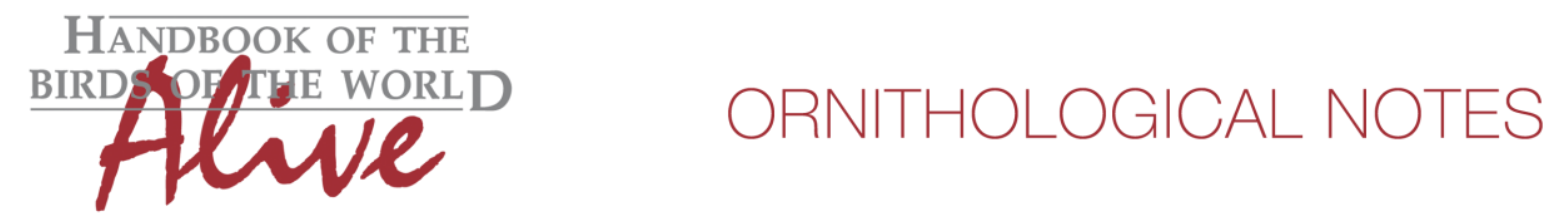

nicobaricus

There are apparently no recordings available on-line, but there is a description in The Ripley Guide including sonogram of 3 examples (Rasmussen \& Anderton 2012). These are somewhat different (but at the same time are rather similar considering the extremely disjunct ranges of both taxa, suggesting there is indeed a close relationship): The introductory high-pitched notes are not described (or unnoticed, as some light specks on the sonograms may be an indication that these introductory notes are lower-pitched, c. $4-6.5 \mathrm{kHz}$ ??). The song phrase of low-pitched whistles has a duration of c. $1.2-1.5 \mathrm{~s}$. Whistles start slowly but typically accelerate and may end in a short trill. Freq. range $1.5-2.9 \mathrm{kHz}$.

More recordings are needed to confirm whether most songs fall within the ranges mentioned above. If so, vocal difference could be scored as follows:

Song of nicobaricus lacks high-pitched intro notes (or in a lower frequency range?) (2), whistled phrase is slightly longer with more notes (score 2-3) and has a slightly higher pace towards the end (score 2). This would lead to a total vocal score of 4.

This note was finalized on 7th May 2016, using sound recordings available on-line at that moment. We would like to thank in particular the sound recordists who placed their recordings for this species on XC: Qin Huang, Frank Lambert, Yong Ding Li and Jonathan Martinez.

\section{References}

Rasmussen, P.C. \& Anderton, J.C. (2012). Birds of South Asia: the Ripley Guide. Second edition. Lynx Edicions, Barcelona.

Tobias, J.A., Seddon, N., Spottiswoode, C.N., Pilgrim, J.D., Fishpool, L.D.C. \& Collar, N.J. (2010). Quantitative criteria for species delimitation. Ibis 152(4): 724-746.

\section{Recommended citation}

Boesman, P. (2016). Notes on the vocalizations of Brown-chested Jungle-flycatcher (Rhinomyias brunneatus). HBW Alive Ornithological Note 318. In: Handbook of the Birds of the World Alive. Lynx Edicions, Barcelona. (retrieved from http://www.hbw.com/node/1251947 on 18 October 2016). 